International Journal of Business and Management Review

Vol.10, No.1, pp.44-56, 2022

Print ISSN: 2052-6393(Print),

Online ISSN: 2052-6407(Online)

\title{
THE DETERMINANTS OF BANK PROFITABILITY: CASE OF TUNISIA
}

\author{
Mohamed Aymen Ben Moussa \\ Department of Management; University Tunis El Manar ; Faculty of Economic Sciences and \\ Management of Tunis; Tunisia
}

\section{Adel Boubaker}

Department Of Finance; University Tunis El Manar; Faculty of Economic Sciences and Management of Tunis

\section{Abdelmonem Naimi \\ Faculty of Economic Sciences and Management of Tunis}

\begin{abstract}
The purpose of this article is to examine the impact of selected internal and external factors on a bank's profitability. The research investigates the impact of size; liquidity ; operating costs ; deposits ; credits ; GDP growth and inflation change of the profitability of sample of 11 banks in Tunisia for the period (2000...2018). The determinants were used to construct 2 models with ROA and ROE as a proxies and regression analysis using panel approach. It was found that size; bank deposit ; operating costs ; liquidity ; economic growth have a significant impact on bank profitability measured by ( ROA and ROE).
\end{abstract}

KEY WORDS: profitability; ROA; ROE; panel, bank, profitability

JEL classification: G21, G23; D08

\section{INTRODUCTION}

Profitability is very important in bank's business affairs just as in other business as they need to generate sufficient profit so as to maximize shareholder's wealth in form of payment or capital appreciation of shares and for growth and expansion .Profitability in the banking sector according to Olarenjn (2015) is a measure of how efficient bank performs its intermediation role and the extent to which it is able to render quality services to customer. In this article we attempt to study the determinants of the profitability of the banking in Tunisia. We employ a methodology of three sections. The first section is devoted to literature review the second section is about the empirical study. We finish by making a conclusion.

\section{LITERATURE REVIEW}

Clearly, bank profitability matters for financial stability. Profits are the first line of defense against losses from credit impairment. Retained earnings are an important source of capital, enabling banks to build strong buffers to absorb additional losses. Those buffers ensure that banks are able to provide financial services to euro area households and businesses, even in the face of adverse developments, thereby smoothing rather than amplifying the impact of negative shocks on the real economy (www.ecb.europa.eu).It is important to know the important

ECRTD-UK https://www.eajournals.org/

Journal Level DOI : https://doi.org/10.37745/ijbmr.2013 
Print ISSN: 2052-6393(Print),

determinants of ban profitability .There are several studies about the determinants of bank profitability. Jawad and Lahsan(2018) used a sample of 6 Moroccan banks during the period 2010-2016. The findings show that only operating management efficiency measured by cost to income ratio is highly significant and negatively related to bank profitability. The bank size is positively related to ROA and statistically significant.

Lawa and al (2017) used a panel banks that account about $8 \%$ of the bank assets in South Africa. The study was conducting using random effect panel data. The resultants revealed that nonperforming loans; capital adequacy; GDP; market price are the main determinants of bank profitability. Also Horobert and et al (2021) investigated the determinants of bank profitability in CEE countries between $(2009 . . .2018)$. They demonstrated that unemployment rate; inflation; budget balance; non-government credit; non-performing loans; concentration rate and capitalization rate are negatively important on bank profitability.

Lee (2018) used pooled ordinary least squares; random effect and 2 step GMM models over the period (2003 ...2016) for banks in Malaysia. The results indicate that capital strength; bank size; remuneration of the board of directors; the duality of the CEO Chairman and economic growth have a positive effect on bank profitability. Whereas management efficiency; liquidity and loan growth have a negative impact on bank profitability. AL Harbi ( 2019) uses ordinary least squares fixed effect model on unbalanced panel data set of all conventional banks operating in OIC countries over the period(1989...2008).The results suggest that equity ; foreign ownership ; off balance sheet activities ; real interest rate and concentration foster bank's profitability . In addition the results showed that the banking sector development and loans will increase bank profitability; in the long run. In contrast; the study reported that deposits lower profitability. The study also revealed that GDP per capital; market capitalization and bank size has no impact on profitability.

Besides; Chouikh and Blagui (2017) used a sample of 7 private banks and 3 state owned banks in Tunisia over the period (1997...2015). They found a negative and significant relationship between bank profitability and board size .Caliskan; Lecuna (2020) investigated the determinants of the banking sector profitability in Turkey for the years between (1980..2017). They found that macroeconomic indicators such as inflation ;interest rate and exchange rate play a significant role in shaping the performance of the banking system .Lemi and et al (2020) used a sample of 7 banks in Ethiopia over the period ( 2000...2017). The results of the study showed statistically significant negative impact of broad money supply and credit risk. Inflation and GDP growth on the other hand was found with significant positive impact. Cash reserve ratio and bank size showed not significant impact on the profitability of commercial banks .Akoi and Andrea ( 2020) used 8 public banks in Turkey from the period ( 2001...2008). The results showed that an increase in bank deposits increase bank profitability. The findings also revealed that an increase in inflation and economic growth had inelastic positive effect on bank profitability.

Shamim et al (2018) used a sample of 12 local banks in Saudi Arabia for the period (2009...2015). The research concludes that bank internal factors specifically bank size; 
liquidity; credit risk and operational efficiency are significantly determining the profitability of bank. Achraf et al (2017) used a sample of banks in different Asian countries over the period (2008...2015). They suggest that ban specific and macroeconomic determinants have strongly influence on bank's profitability. Nessibi Olfa (2016) examined how bank's specific characteristics and macroeconomic indicators affect the profitability in the Tunisian banking industry over the period $(1990 \ldots 2018)$. The results indicated that the more profitable banks are those higher amount of capital and lower operating costs. Furthermore it appears that private banks tend to perform better than state owned. Despite the great importance given to the board of directors; it doesn't have a dominant role. In the Tunisian commercial banks the real interest rate has a positive effect on bank profitability.

Also Ghodrati and Ghasemi (2014) studied different factors on return on assets and return on equity on 18 Iranian banks over the period (2002...2011). The study considers total assets; ownership assets; deposits to asset ratios and loan to asset ratio as independent variables. ROA and ROE as dependent variables. The results indicate that the private banks return over better than governmental banks and the commercial bank's returns were better than special banks. Jadah et al (2020) used unbalanced panel date from 18 banks in Iraq for the period (2005...2017). The results showed that bank size ; equity / assets ; loan / total assets ; GDP growth and government effectiveness have a significant and positive effect on the profitability of Iraqi banks .Sanyalou et al (2019) investigated bank specific and macroeconomic determinants of profitability of 10 listed deposit money market banks in Nigeria stock exchange from $(2008 \ldots 2017)$. The results revealed that capital adequacy ratio; non-performing loans; loan to total assets and size have significant effect on profitability while age was found to exert significant but negative effect on profitability.

The study could not however establish significant positive effect of macroeconomic indicators ( economic growth and interest rate ) on profitability of deposit money banks while inflation rate has negative but insignificant influence on profitability .Besides ; Thanh and Ngorc (2019) studied 10 vietnamese listed commercial bank for the period (2008...2013). The results showed that operating efficiency ; loan size ; retail loan ratio ; state ownership ;inflation rate and GDP growth are factors that have a positive impact on profitability .But variables such a size ; credit risk ; capital ; liquidity risk ; revenue diversification and statistically insignificant .On the other hand Al Homaidi et al (2020) examined the impact of internal and external determinants of 37 commercial banks profitability listed on Bombay stock exchange in India for the period ( 2008...2017). The results shows that bank size; assets; liquidity; asset management quality and net interest margin are important determinants which affect ROA. Capital adequacy; deposits; operating efficiency; gross domestic product and inflation rate are found to have a negative significant impact on ROA.

\section{Empirical study}

The determinants of bank profitability has been the object of several researches. Under this section; we will identify the sample at the beginning and then we specify the variables and the models. After we carry out the necessary econometric tests: Finally we show the estimation results of the model and their interpretations. 
Print ISSN: 2052-6393(Print),

\section{Sample}

We will use 11 banks ( BIAT ; STB ; BNA ; BH ; ATB ; AMEN Bank ; BH ; BTEI ; BT ; Attijari bank ; UBCI ) that belong to professional association of banks in Tunisia and quoted in Tunisian sotck exchange over the period (2000...2018) Financial data are collected through the annual report of banks existed in the website of the professional association of banks in Tunisia over the period ( $2000 \ldots 2018$ )

\section{Estimation method}

We will utilize panel static because it controls:

-The time and individual variation in the observable behavior across sectional times series aggregated.

-The observed or unobserved individual heterogeneity

\section{Specification of variables}

We will estimate the following models:

(1) ROA i,t $=$ b0+ b1 Sizei;t +b2 CAPi;t +b3 TLAi;t +b4 CEAi,t +b5 CFCi;t +b6 Tdeposit $\mathrm{i} ; \mathrm{t}+\mathrm{b} 7$ CEAi,t +b8 CFCi,t +b9 ALA i,t +b10 CD i,t +b11 TPIBt +b12 TINFt +Ei,t

(2) ROEi,t $=$ b0+ b1 Size i,t +b2 CAPi,t +b3 TLAi,t +b4 CEAi,t +b5 CFCi,t +b6 Tdepositi,t +b7CEAi, t +b8 CFCi,t +b9 ALAi,t +b10 CDi,t +b11 TPIBi,t +b12 TINFi,t +Ei,t

Where: $\mathrm{i}=$ Bank

$\mathrm{T}=$ Time

$\mathrm{b} 0=$ constant

b $1 ; \mathrm{b} 2 ; \mathrm{b} 3 ; \ldots \ldots . . . \mathrm{b} 12=$ parameters to be estimated

We test the following hypothesis:

H1: Capital has a significant effect on bank profitability

H2: Deposits has a significant effect on bank profitability

H3: Size has a significant effect on bank profitability

H4: Operating costs has a significant effect on bank profitability

H5: Loans has a significant effect on bank profitability

H6: Inflation has a significant effect on bank profitability

H7: Economic growth has a significant effect on bank profitability

$\mathrm{ROA}=$ return on assets $=$ net income/ total assets

ROA shows how to generate income from the assets of the bank (Chin (2011).

It measures the profit earned per dollar of assets and reflects how well management uses the bank's investment resources has generate profit ( Naceur (2003).

ROA is considered as the best proxy of profit ( Flamini ; al ( 2009); Samad ( 2005).

$\mathrm{ROE}=$ return on equity $=$ Net income $/$ total equity

ROE reflects the ability of bank to use its own funds to generate profits ( Yilmaz 2013). 
This ratio shows the profit earned per 1 dinar of investment. This is an indicator of how well banks uses investor's money or generate profit (Chowikh ; Blagui 2017).

Size $=$ size of the bank $=$ Natural logarithm of total assets

Size can show the economies of scale. The large banks benefits from economies of scale which reduces the cost of production and information gathering (Boyd; Runkhle 1993).

ALA = liquid assets / total assets

ALA depicts the bank's ability to absorb the liquidity shocks. In theory the higher liquidity ratio indicates that the bank is better position to meet its stochastic with drawals (Chagwiza 2014).

$\mathrm{CEA}=$ operating expenses / total assets

Operating expenses including personal expenses and other expenses. CEA shows the weight of operating expenses compared to total assets

$\mathrm{CFC}=$ Financial expenses $/$ total credits

Financial expenses include interest expenses due to loan made in the money market and the capital market by banks.

CFC shows the financial expenses in relation to total credits

\section{Tdeposits $=$ Total deposits $/$ total assets}

Deposits include demand deposit and term deposits. T deposits shows the share of deposits compared to total assets. The more the deposit a bank collect; the more the loan opportunities; it will be able to generate further profits (Mencucci and Paolucci 2016).

\section{$\mathrm{CD}=$ total credits / total deposits}

It is the ratio that describes how allocation of funds in term of deposits; comparing to a number of funds which is obtained from savings (Widyastuti et al 2017). When the ratio is higher; it show more risky conditions because the funds from deposits have been collected in more of credits. Conversely the lower ratio indicate effective banks in lending decision.

\section{TPIB = Growth rate of gross domestic product}

It shows the growth in the economic activity in the country.

TINF $=$ rate of inflation. It is known as a specific or sustained increase in the actual price of the commodities in the economy over a certain period. Inflation has a lot to do with the banks as it fluctuate of the bank to balance the economy. (Al mansour and al (2021)). 
Print ISSN: 2052-6393(Print),

Online ISSN: 2052-6407(Online)

\section{Descriptive statistics}

\begin{tabular}{|l|l|l|l|l|l|}
\hline & Observations & Mean & $\begin{array}{l}\text { Standard } \\
\text { deviation }\end{array}$ & Minimum & Maximum \\
\hline ROA & 209 & 0.0117 & 0.0100 & 0 & 0.0975 \\
\hline ROE & 209 & 0.1047 & 0.06077 & 0 & 0.2976 \\
\hline & & & & & \\
\hline Size & 209 & 15.013 & 1.017 & 11.93 & 18.29 \\
\hline CAP & 209 & 0.1162 & 0.096 & 0 & 0.6739 \\
\hline TLA & 209 & 0.7569 & 0.131 & 0.107 & 0.9817 \\
\hline CEA & 209 & 0.02841 & 0.0063 & 0.000237 & 0.056 \\
\hline CFC & 209 & 0.03677 & 0.0207 & 0.0184 & 0.03051 \\
\hline T deposit & 209 & 0.7421 & 0.1599 & 0.0205 & 0.756 \\
\hline ALA & 209 & 0.03494 & 0.037 & 0.0033 & 0.044 \\
\hline CD & 209 & 1.5292 & 2.83 & 0.1852 & 35.76 \\
\hline TPIB & 209 & 0.03310 & 0.0147 & 0.0012 & 0.0811 \\
\hline TINF & 209 & 0.05529 & 0.05356 & 0.03 & 0.0781 \\
\hline
\end{tabular}

\section{$209=11 * 19$}

$11=$ Number of banks

$19=$ Number of years $(2000 \ldots .2018)$

ROA (mean $=\mathbf{0 . 0 1 1 7}$ ). In the average; net return represent $1.17 \%$ of total assets. Standard deviation is low (1\%). There is no great difference between banks in ROA. Also ROE (Mean $=\mathbf{0 . 1 0 4 7}$ ). In the average; net profit represent $10.47 \%$ of total assets. Standard deviation is high $(6 \%)$. There is no great difference between banks in ROE. Besides; On the other hand; Size (mean $=\mathbf{1 5 . 0 1 3}$ ). In the average; size of bank equal to 15. Standard deviation is high. There is a big difference between banks in size.

CAP $($ mean $=\mathbf{0 . 1 1 6 2})$. In the average; capital of bank equal to $11.62 \%$ of total assets. Standard deviation is high. There is a big difference between banks in Capital. Also TLA (mean = $75.69 \%$ ). In the average total credit represents $75.69 \%$ of total assets. There is a big difference between banks in TLA. The banks is differently in TLA.

CEA ( mean $\mathbf{= 0 . 0 2 8 4 1}$ ). The operating expenses represent an average $2.841 \%$ of total assets. There is a low standard deviation. There isn't big differences between banks in term of CEA. On the other hand; CFC (mean $=0.03677$ ). In average financial expenses represent $3.677 \%$ of total credits.

T deposit (mean $=\mathbf{0 . 7 4 2 1}$ ). In average total deposits represent $74.21 \%$ of total assets. The standard deviation is high. There is a big difference between banks in term of deposits.

ALA (mean =0.034). In average asset liquid represent $3.4 \%$ of total assets. There is not high standard deviation. There isn't big difference between banks in term of ALA. Besides CD (mean=1.52). In average total credit represent 1.52 of total deposits. There is a high standard deviation. There is a big difference between banks in term of CD. 
Print ISSN: 2052-6393(Print),

Online ISSN: 2052-6407(Online)

TPIB (mean=0.033). In average economic growth equal to $3.33 \%$ in the period of study $(2000 \ldots 2018)$. There is a low standard deviation. There is no big difference between years in economic growth except the years after revolution of 2011 who the economic growth has dropped.

TINF (mean $\mathbf{5 . 5 2 \%}$ ). In average the rate of inflation equal to $5.52 \%$ in the period of study (2000...2018). There is a low standard deviation. There is a big difference between years in inflation except the years after revolution of 2011 who the inflation has increased.

Multicolinearity test

Table1: correlation between variables

\begin{tabular}{|l|l|l|l|l|l|l|l|l|}
\hline & ROA & ROE & Size & CAP & TLA & CEA & CFC \\
\hline ROA & 1.000 & & & & & & & \\
\hline ROE & 0.3930 & 1.000 & & & & & & \\
\hline & & & & & & & & \\
\hline Size & 0.0158 & 0.3964 & & 1.000 & & & & \\
\hline CAP & 0.2435 & -0.2316 & -0.4941 & 1.000 & & & \\
\hline TLA & 0.0933 & 0.0639 & 0.1256 & 0.09781 & 1.000 & & \\
\hline CEA & 0.0524 & -0.0157 & 0.1215 & -0.0841 & -0.0628 & 1.000 & \\
\hline CFC & -0.0056 & 0.0089 & 0.1200 & -0.0915 & -0.2040 & 0.2885 & 1.000 \\
\hline
\end{tabular}

Table 2: Suit of correlation between variables

\begin{tabular}{|c|c|c|c|c|c|c|c|c|}
\hline & ROA & ROE & Size & CAP & TLA & CEA & CFC & Tdeposit \\
\hline Tdeposit & $\begin{array}{l}-0463 \\
0.04\end{array}$ & 0.3751 & 0.534 & $\begin{array}{l}- \\
0.7636\end{array}$ & 0.0528 & $\begin{array}{l}- \\
0.0738\end{array}$ & 0.0303 & 1.000 \\
\hline ALA & $\begin{array}{l}- \\
0.0920\end{array}$ & $\begin{array}{l}- \\
0.1441\end{array}$ & -0.0794 & $\begin{array}{l}- \\
0.0619\end{array}$ & $\begin{array}{l}- \\
0.0700\end{array}$ & -0.374 & -0.036 & -0.0849 \\
\hline CD & 0.2313 & $\begin{array}{l} \\
0.1557\end{array}$ & -0.3739 & 0.7434 & 0.0517 & $\begin{array}{l}- \\
0.1049\end{array}$ & -0.063 & -0.59 \\
\hline TPIB & 0.0685 & $\begin{array}{l}- \\
0.1856\end{array}$ & -0.3656 & 0.0522 & $\begin{array}{l}- \\
0.1881\end{array}$ & $\begin{array}{l}- \\
0.0532\end{array}$ & 0.021 & -0.1314 \\
\hline TINF & 0.0427 & 0.0486 & 0.1247 & $\begin{array}{l}- \\
0.0160\end{array}$ & 0.1440 & 0.0418 & $\begin{array}{l}- \\
0.0038\end{array}$ & 0.0753 \\
\hline
\end{tabular}

Table 3: Suit of correlation between variables

\begin{tabular}{|l|l|l|l|l|}
\hline & ALA & CD & TPIB & TINF \\
\hline ALA & 1.000 & & & \\
\hline CD & -0.0598 & 1.000 & & \\
\hline TPIB & 0.1226 & 0.0628 & 1.000 & \\
\hline TINF & -0.0834 & -0.0186 & -0.2389 & 1.000 \\
\hline
\end{tabular}


Print ISSN: 2052-6393(Print),

Online ISSN: 2052-6407(Online)

Multicolinearity occurs when there is a high correlation between the independent variables in the regression analysis which impacts the overall interpretation of the results it reduces the power of coefficients and weakens the statistical measure to test the $\mathrm{p}$ value is identify the significant independent variables. All coefficients between variables are inferior to $80 \%$. There is no problem of multicolinearity

Test of VIF

\begin{tabular}{|l|l|l|}
\hline Variables & VIF & $\mathbf{1 / V I F}$ \\
\hline CAP & 3.87 & 0.25 \\
\hline Tdeposit & 2.97 & 0.33 \\
\hline CD & 2.27 & 0.44 \\
\hline Size & 1.74 & 0.57 \\
\hline TPIB & 1.26 & 0.79 \\
\hline CEA & 1.18 & 0.84 \\
\hline CFC & 1.15 & 0.86 \\
\hline TLA & 1.15 & 0.86 \\
\hline TINF & 1.08 & 0.91 \\
\hline ALA & 1.07 & 0.93 \\
\hline
\end{tabular}

VIF quantifies the extent of correlation between one predictor and other predictors in a model. High value signifies that is difficult to assess accurately the contribution of predictors to a model.

\section{Hausman test}

The Hausman test is developed to give existence in deciding on electing between the field effects and random effect approach.

The hypotheses of the hausman test are: H0: Random effect are consistent and efficient

\section{H1: Random effect are inconsistent}

When the pvalue is greater to 0.05 the random effect is chosen

In Model 1: $\mathrm{Pv}=0.0534$

Model 2: $\mathrm{Pv}=0.068$ 
Print ISSN: 2052-6393(Print), Online ISSN: 2052-6407(Online)

Estimation of result of models and interpretations $A$ - Estimation of result of model 1 and their interpretations

\begin{tabular}{|l|l|l|l|l|l|}
\hline ROA & Coeff & Std.error & $\mathbf{Z}$ & $\mathbf{Z}<\mathbf{P}$ & $\mathbf{9 5 \%}$ CI \\
\hline Size & 0.0015 & 0.00085 & 2.072 & 0.015 & -0.00013 \\
& & & & & 0.0032 \\
\hline CAP & 0.049 & 0.013 & 1.073 & 0.000 & 0.0220 .075 \\
\hline TLA & 0.0023 & 0.0053 & 0.663 & 0.663 & $\begin{array}{l}-0.0081 \\
0.0128\end{array}$ \\
\hline CEA & -0.1998 & 0.112 & 2.077 & 0.014 & -0.0210 .42 \\
\hline CFC & -0.0079 & 0.033 & 0.814 & 0.8140 & -0.0740 .058 \\
\hline Tdeposit & 0.0213 & 0.0070 & 0.003 & 0.003 & 0.00740 .035 \\
\hline ALA & -0.0063 & 0.0181 & 2.726 & 0.013 & -0.0420 .029 \\
\hline CD & 0.00050 & 0.00034 & 0.149 & 0.149 & -0.00018 \\
& & & & & 0.0011 \\
\hline TPIB & 0.1090 & 0.049 & 2.029 & 0.019 & 0.0110 .206 \\
\hline TINF & 0.0064 & 0.01270 & 0.611 & 0.611 & -0.0184 \\
& & & & & 0.031 \\
\hline Cons & -0.040 & 0.0142 & 0.002 & 0.002 & -0.072 \\
& & & & & 0.0165 \\
\hline
\end{tabular}

-There is a positive relationship between ROA and size if size increase by $1 \%$ : ROA will be increased by $0.0015 \%$ ). The increase of size has a positive effect on return on assets. This result is similar to result found by Menicucci ; Paolucci ( 2016) : Serwaddad (2018) but contrary to result found by Pasiouras ; Kosmidou ( 2007) ; Athansoglou et al ( 2008).

Large banks might benefit from economies of scope economies ( Menicucci ; Paolucci 2016). Also there is a positive relationship between ROA and CAP (if CAP increase by $1 \%$; ROA will be increased by $0.049 \%$ ) The increase of capital has a positive effect on return on assets of bank. This result is similar to result found by (Trujillo; Ponce 2013; Dhouibi 2017).

A high volume of equity will reduce the cost of capital; causing a positive effect on profitability. Therefore well capitalized banks achieve greater profitability ( Menicucci ; Paolucci 2016).

There is a positive relationship between ROA and TLA (if TLA increase by 1\%; ROA will increase by $0.0023 \%$ ). The increase of total credits by total assets has a positive effect on return on assets of bank. This result is similar to result found by ( Meniccuci ; Paolucci 2016).

There is a positive relationship between CEA and ROA (if CEA increase by 1\%: ROA will decrease by $0.1998 \%$ ). The increase of operating expenses has a negative effect on bank return on assets. This result is similar to result found by (Athansoglou at al 2008 ; Kosmidou et al 2005).

The negative effect of cost means that there is a lack of competence in expense management since banks pass part of increased costs to customers and the remaining parts to profits; possibly due to the fact that competition does not allow them to overcharges Athansoglou et al (2008)). Besides there is a negative relationship between CFC and ROA (if CFC increase by 1\%; ROA 
Print ISSN: 2052-6393(Print),

will be decrease by $0.0079 \%$ ). The increase of financial expenses by credits has a negative effect on return on assets.

There is a positive relationship between $\mathrm{T}$ deposit and ROA (if $\mathrm{T}$ deposit increase by 1\%; ROA will increase by $0.0213 \%$ ). The increase of deposit has a positive effect on return on assets of banks. There is a negative relationship between ALA and ROA (if ALA increase by $1 \%$; ROA will increase by $.0063 \%$ ). The increase of asset liquid has a negative effect on return of assets. Also there is a positive relationship between CD and ROA (if CD increase by 1\%; ROA will increase by $0.0050 \%$ ). The increase of credits by deposits has a positive effect on return on assets. This result is similar to result found by Hassan; Bashir (2003); Baracoa (2018) but contrary to result found by Pruwoko ; Sudyatno (2013).

There is a positive relationship between TPIB and ROA (if TPIB increase by 1\%; ROA will increase by $0.1090 \%$ ). The increase of economic growth has a positive effect on return on assets of bank. This result is similar to result found by (Dietrich; Wanzenried 2011) ;Jawad, Lahsen 2018)but contrary to result found by ( Blagui; Chouikh 2017). There is a positive relationship between TINF and ROA (if TINF increase by $1 \%$; ROA will increase by $0.0064 \%$ ) . The increase of rate of inflation has a positive effect on bank return of assets. This result is similar to result found by (Pasiouras ; Kosmidou 2007; Lemin and et al 2020); Karadazic and Dalovic 2021) but contrary to result found by ( Chitha 2018 ; Almansour et al 2021; Nyabakora and al 2020 ; Ebrahimi et al (2021).

\section{Estimation of results and interpretations of model 2}

Table : Estimation of results of model 2

\begin{tabular}{|l|l|l|l|l|l|}
\hline ROE & Coeff & Std .error & $\mathbf{Z}$ & $\mathbf{Z}<\mathbf{P}$ & 95\% CI \\
\hline Size & 0.01668 & 0.0049 & $3.37 * * *$ & 0.001 & 0.00690 .026 \\
\hline Cap & 0.07381 & 0.077 & 0.95 & 0.341 & -0.0780 .22 \\
\hline TLA & -0.0068 & 0.031 & -0.22 & 0.827 & -0.0670 .054 \\
\hline CEA & -0.062 & 0.65 & -2.536 & 0.015 & -1.340 .21 \\
\hline CFC & -0.068 & 0.19 & -0.35 & 0.728 & -0.450 .30 \\
\hline T deposit & 0.1295 & 0.0409 & $3.16^{* * *}$ & 0.018 & 0.0490 .20 \\
\hline ALA & -0.1297 & 0.1054 & -2.253 & 0.017 & -0.330 .076 \\
\hline CD & 0.0013 & 0.002 & 0.66 & 0.511 & -0.0026 \\
& & & & & 0.0032 \\
\hline TPIB & -0.19 & 0.2891 & -2.67 & 0.011 & -0.750 .37 \\
\hline TINF & -0.027 & 0.0736 & -0.38 & 0.7060 & -0.170 .11 \\
\hline Const & -0.23 & 0.082 & -2.79 & 0.005 & -0.390 .066 \\
\hline
\end{tabular}

$(* * *)$ significant at $1 \%$

-There is a positive relationship between size and ROE (if size increase by $1 \%$ ROE will increase by $1.66 \%$ ). The increase of size has a positive effect on return on equity of bank. This relationship is statistically significant at $1 \%$. This result is similar to result found by (Topaz; Talu 2017; Abobaker 2018; Bogale 2019). This result is contrary to found by Gadagbi (2017). 
Print ISSN: 2052-6393(Print),

Finance literature suggests that large banks are said to exhibit lower returns because of the enhanced economies of scale which they may pass on their customers in the form of lower lending rates. There is a positive relationship between CAP and ROE ( if CAP increase by $1 \%$ ; ROE will increase by $7.38 \%$ ). The increase of capital has a positive effect on bank return on equity .This result is similar to result found by (Ahansolgou et al 2008 ; Abobaker 2018). There is contrary to result found by Gadegbi (2017). Banks with a high capital ratio are consistent to be insured against bankruptcy to have access to cheap funds to be more flexible in pursing business opportunities and have to ability to absorb any unexpected losses. There is a negative relationship between ROE and TLA (if TLA increase by $1 \%$; ROE decrease by $0.0068 \%$ ). The increase of TLA has a negative effect on return on equity of bank. This result is similar to result found by Yuksul ; al (2018). Therefore high level of loans means a possible deterioration of the bank asset quality with a negative effect on bank profitability (Alper ; Anbar 2011). There is a negative relationship between ROE and CEA (if CEA increase by $1 \%$ ROE decrease by $0.062 \%)$. The increase of operating costs has a negative impact on bank return on equity. There is a negative relationship between ROE and CFC (if CFC increase by $1 \%$; Roe decrease by $0.068 \%$ ). The increase of financial expenses has a negative impact on bank return on equity.

There is a positive relationship between ROE and T deposit (if T deposit increase by 1\%; ROE will increase by $0.1295 \%$ ). The increase of deposits have a positive impact on bank return on equity. There is a negative relationship between ROE and ALA (if ALA increase by 1\%; ROE will decrease by $0.1297 \%$ ). The increase of asset liquid has a negative impact on bank return on equity. There is a positive relationship between ROE and CD (if CD increase by 1\%; ROE will increase by $0.0013 \%$ ). The increase of credits by deposits have a positive impact on bank return on equity. There is a negative relationship between TPIB and ROE ( if TPIB increase by $1 \%$; ROE will decrease by $0.19 \%$ ). The increase of TPIB have a negative impact on bank return on equity. There is a negative relationship between TINF and ROE (if TPIB increase by $1 \%$; ROE will decrease by $0.027 \%$ ). The increase of TINF have a negative impact on bank return on equity. This result is similar to found by (Ebrahimi et al 2021; Saeed 2014; Sufian ; Chong 2008 ; Ayadin and Karakaya 2014)

\section{CONCLUSION}

Banks are specialized companies with their own specification; banks are more opaque than other companies play a crucial role in financing their economy and take on risky financial activities based on information and trust. The profitability is important in banking industry for effective management and paying the costs of banks. In this article we study a panel model for the sample of 11 banks in Tunisia for the period (2000...2018). We found that size; deposits; operating costs; liquidity and economic growth has a significant impact on bank profitability measured by return on assets and return on equity.

\section{References}

ALharbi.A (2019) " The determinants of conventional banks profitability in developing and underdeveloped OIC countries " Journal of Economic ; Finance and administrative sciences ; vol 24; issue 47 
-Alper .D ; A.Anbar ( 2011) “ Bank specific and macroeconomic determinants of commercial bank profitability : Empirical Evidence from Turkey " Business and Economic research Journal ; vol 2 ; number $2 ; \mathrm{p} 139-152$

-Belescu .E ; Maria Dita .S ( 2021) “Determinants of bank profitability in CEE countries : Evidence from GMM panel data estimates " Journal of Risk and financial management ; vol 14, p1-23

-Bogale Y W ( 2019) "Factors affecting profitability of bank : Empirical evidence from Ethiopian private commercial banks “ Journal of Investment and Management ; vol 8; issue 1; Fabruary ; p8-15

-Boyd .J.H ; D.E. Runkle ( 1993) "Size and performance of banking firms : Testing the predictions of theory " Journal of Monetary Economics ; vol 31; issue 1 ; February ; $p$ 47-67

-Caliskan .M.M.T ; Siva Lecuna .K.K ( 2020) « The determinants of banking sector profitability in Turkey " Business and Economic Research Journal ; vol 11, numéro 1; p161-167

-Chagwiza .W (2014) “ Zimbabwean commercial bank liquidity and its determinants “ International Journal of Empricial Finance ; vol 2; issue 2; p 52-64

-Chouikh .A ; Y..Blagui (2017) “ The determinants of bank performance : The case of Tunisian listed banks "Journal of Finance and Accounting ; vol 5, number 2; p 53-60

-Dietrich .A ; G.Wanzeried ( 2011) "Determinants of bank profitability before and during the crisis " Journal of Financial Markets ; institutions and Money ; vol 21; issue 3; p 307322

-Ebrahimi .P ; M.F.Farkars; P .Bouzai ; R.Magda ( 2021) “Financial performance of Iranian banks from 2013 to 2019 : A panel data approach " Journal of risk and financial management ; vol 14; p1.15

-Flamini .V, C.Mc Donald ; L.Sucmacher (2009) « The dominants of commercial bank profitability in Sub Sahran Africa" IMF working paper ; p 1-30

-Ghodarti .H ; M.Ghasemi ( 2014) “ Determinants of bank profitability “ Management Sciences letter; $\mathrm{p} 759-764$

-Horobet .A ; L.Balescu ; S .Maria dita (2021) “ Determinants of bank profitability in CEE countries : Evidence from GMM panel data estimates " Journal of risk and financial management ; vol14; p-23

-Jadah .H.M ; M.H.A Algharimim ;N.S H Al Dahaan ( 2020) “ Internal and external determinants of Iraqi bank profitability " Banks and banks systems ; vol 15 ; issue 3 ;p 79-93

--Jaouad .E ; O.Lahsen (2018) “Factors affecting bank performance : Empirical evidence from Morocco “European Scientific Journal ; vol 14; 34; p255-267

-Karadzic .V; N.Dalovic ( 2021) " Profitability determinants of Big European bank "Journal of central banking theory and practice ; vol 10, 2; p39-56

-Lemi .B.A ; M.K Rafeera ; M.Gezaw ( 2020) " Macroeconomic and bank specific determinants of commercial ban profitability in Ethiopia " International Journal of Commerce and Finance ; vol 6;issue 2 ; p198-206 
Print ISSN: 2052-6393(Print),

-Menicucci .E ; G.Palucci ( 2016) “ The determinants of bank profitability : Evidence from European banking sector "Journal of Financial reporting and accounting ; vol 14 ; p 86115

-Naceur .S.B (2003) “ The determinants of the Tunisian banking profitability : Panel evidence 66

-Nessibi .O ( 2016) " The determinants of bank profitability :case of Tunisia " International Journal of finance and banking studies ; vol 5 , number 1, p39-50 , January

-Pasiouras .F ; K.Kosmidou ( 2007) “ Factors influencing the profitability of domestic and foreign commercial banks in the European Union " Research in International Business and finance, vol21; 2,p222-231

-Serwadda .I ( 2018) "Impact of credit risk management systems on the financial performance of commercial banks in Uganda " Mendel University Press ; vol 66; 6; p1627-1635

-Shamim .F ; B.Akhtan ; M.A.Abulla ;N.D Y Sukki (2018) “ Bank specific vs macroeconomic factors :what drives profitability of commercial banks in Saudia Arabia "Banks and bank systems ; $13 ; 1 ;$ p139-149

-Thanh . P.T ; H.T.Ngorc ( 2020) “ The determinants of listed commercial bank's profitability in Vietnam "The journal of Asian ; Finance ; Economics and Business ; vol 7 issue 11; p219-229

-Topak.M.S ; NH Talu ( 2017) “ Bank specific and macroeconomic determinants of bank profitability evidence from Turkey "International Journal of Economic and Financial issues ; 7,2 , p 574-584

-Yilmaz .A.A.Y ( 2013) “ Profitability of banking system : Evidence from Emerging markets “ WEI international Academic conference paper ; January , p 14-16

-Yuksel .S.S Mutkhtarov; E .Mammadov; M .Ozsai ( 2018) "Determinants of profitability in the banking sector : An analysis of Post soviet countries "Economies ; 6; 41; p1-15 